\title{
Somina (Herbal preparation): partial muscarinic agonist
}

\begin{abstract}
Purpose: To evaluate the agonistic property of somina (herbal drug) on muscarinic receptor.

Methods: For determination of effect of somina on receptor rabbit heart was in the Langendorff apparatus coupled with four channels Harvard Universal Oscillograph. The heart was perfused with different solutions like; Somina $(20 \mathrm{mg} / \mathrm{ml})$, Ach $10^{-3}$, Atr $10^{-3}+$ somina, Atr $10^{-3}+$ Ach $10^{-3}$ and Somina $(20 \mathrm{mg} / \mathrm{ml})+$ Ach $10^{-3}$ and effect on heart rate was recorded. The records were used for the calculations of heart rate (beat per min).
\end{abstract}

Results: Somina and Ach $10^{-3}$ caused significant $(\mathrm{p}<0.05)$ reduction in heart rate $(28 \%$ and $52 \%$ respectively) however non significant reduction in heart rate was observed ( 3 and $11 \%, p>0.05$ ) after atropine treatment. Receptor activity confirms that Somina act on Ach receptors. 33\% reduction in heart rate was observed after perfusion with Somina $(20 \mathrm{mg} / \mathrm{ml})+$ Ach $10^{-3}$. Somina competing with Ach $10^{-3}$ (the full agonist) for the same muscarinic receptor and thereby reducing the ability of the full agonist to produce its maximum effect (Ach $10^{-3} 52 \%$; Somina + Ach $10^{-3} 37 \%$ reduction) when both full agonist (Ach) administered simultaneously with somina.

Conclusion: Somina is a partial agonist at non-selective muscarinic receptors.

Keywords: somina, herbal preparation, heart rate, muscarinic receptor, partial agonist
Volume 2 Issue 5 - 2015

\author{
Muhammad Ahmed,' Aisha Azmat ${ }^{2}$ \\ 'Department of Pharmacology, Saudi Arabia \\ ${ }^{2}$ Department of Physiology, Saudi Arabia
}

Correspondence: Muhammad Ahmed, Department of Pharmacology, Faculty of Pharmacy, Umm-Al-Qura University, Makkah, Saudi Arabia, Tel 00966-025270000 ext 4282, 00966556618257, Email hma00ahmed@hotmail.com

Received: May 29, 20I5 | Published: July 25, 2015

\section{Introduction}

Many herbal formulated preparations are used in folk medicine as remedies for the treatment of a variety of human ailments from time immemorial. One of the traditional medicine "Somina" is one of the traditional medicine, formulated by Hamdard laboratories (Waqf) Pakistan. It is claimed that Somina is a cephalic tonic having sedative, hypnotic and anxiolytic activities. It is also claimed that somina is effective in weakness of brain and memory. Previously researcher has suggested that somina affect brain serotonin levels and enhances the memory. Five Medicinal plants in different ratio are present in Somina. Sesamum indicum (14\%), Lagenaria vulgaris (12\%), Prunus amygdalus (12\%), Papaver somniferum (10\%) and Lactuca scariola $(5 \%)$. These medicinal plants not only affect the brain activity but affect the cardiac activity like Sesamum indicum (14\%) prevent the high blood pressure, ${ }^{1}$ Prunus amygdalus $(12 \%)$ decrease the coronary heart disease risk, ${ }^{2}$ Papaver somniferum $(10 \%)$ protect against heart attacks, ${ }^{3}$ Lactuca scariola (5\%) is a vasorelaxant ${ }^{4}$ and Lagenaria vulgaris $(12 \%)$ worked as cardio-protective. ${ }^{5}$ Previous studies suggest that somina stimulates the muscarinic receptor and reduced the heart rate and mean arterial Blood Pressure. In the light of previous reported data it was concluded the somina is a muscarinic receptor agonist. Now-a-days, common drugs have been classified according to their receptor activity like buspirone, aripiprazole and buprenorphine classified as partial agonists. ${ }^{6}$ However, still it is not confirmed that somina is a full agonist or partial agonist that's why the present study was planned to further confirm the agonistic property of somina on rabbit isolated heart preparation.

\section{Materials and methods}

\section{Herbal preparations (Somina)}

A patent formulation of Hamdard laboratories, Waqf. Pakistan (Somina) was obtained in the form of crumb/powder. $20 \mathrm{mg} / \mathrm{ml}$ dose of somina were used in this experiment as this dose was said to be maximum effective dose. Somina $(20 \mathrm{mg} / \mathrm{ml})$ were freshly prepared by dissolving somina in warm distilled water for experimental use.

Kreb's Henseleit buffer solution: Kreb's Henseleit Buffer solution was used for perfusion. The composition of solution was $118 \mathrm{mM}$; $\mathrm{NaCl}, 4.70 \mathrm{mM} ; \mathrm{KCl}, 1.25 \mathrm{mM} ; \mathrm{CaCl}_{2}, 1.20 \mathrm{mM} ; \mathrm{MgSO}_{4}, 25 \mathrm{mM}$; $\mathrm{NaHCO}_{3} \& 11 \mathrm{mM}$ Glucose. All chemicals were obtained from E-Merck, Germany.

Animals: Rabbits (Oryctolagus cunniculus) of either sex ranging from 1.0-2.0 Kg were used for experiments. The Standing Research Committee on Animal Research and Ethics from our institution approved the animal handling protocol.

\section{Experimental procedure}

These experimental animals were killed by decapitation and heart was isolated with intact aorta immediately and mounted in the Langendorff apparatus coupled with four channels Harvard Universal Oscillograph. The heart was perfused at a constant pressure retrogradely with filtered Krebs-Henseleit solution saturated with $95 \% \mathrm{O}_{2}+5 \% \mathrm{CO}_{2}$ and regulated at $37^{\circ} \mathrm{C}$. Ventricular activity of heart was recorded through isotonic transducer on Oscillograph. After 
the stabilization of the heart, it was then perfused with different solutions like; Somina $(20 \mathrm{mg} / \mathrm{ml})$, Ach $10^{-3}$ for comparison, Atr $10^{-3}+$ somina, Atr $10^{-3}+$ Ach $10^{-3}$ for receptor activity and Somina (20mg/ $\mathrm{ml})+$ Ach $10^{-3}$ for agonist activity on different animals. Care was taken to administer a single dose for at least 3 to 5 minutes before taking records of heart activity. After recording, the heart was washed with normal solution for 10-15 $\mathrm{min}$, before the same/second dose was tested for next observation. For every observation, the activity recorded before administration of any dose was considered as control. A total of 15 rabbits were used in the present study. The records were used for the calculations of heart rate (beat per min).

\section{Statistical analysis}

All the data was normalized to percent of control. And the standard statistical tools, i.e., mean and Standard Errors were determined for its analysis.

\section{Results}

Somina $(20 \mathrm{mg} / \mathrm{ml})$ produced a negative chronotropic effect on heart as compared to its control. The reduction in heart rate (negative chronotropic effect) was $28 \%$ as compare to their controls (Table 1). While, after $\operatorname{Atr}\left(10^{-3} \mathrm{M}\right)$ pretreatment, $20 \mathrm{mg} / \mathrm{ml}$ Somina was found to decrease the heart rate non significantly $(\mathrm{p}>0.05)$. This reduction was $3 \%$ than its control (Table 1 ). Ach $10^{-3}$ had demonstrated a decrease in heart rate that was $52 \%$ than its respective control. Further, in Atr $\left(10^{-}\right.$ $\left.{ }^{3}\right)$ pre-treated heart, the Ach $\left(10^{-3}\right)$ did not show such decline in heart rate as shown earlier. The reduction in heart rate is decline with Atr $\left(10^{-3}\right)$ pre-treatment was only $11 \%$ than its control. Single treatment of somina cause $28 \%$ and Ach $10^{-3}$ caused $52 \%$ reduction. For the determination of agonist activity both were administered at the same time cause a total $37 \%$ reduction in heart rate (Table 1 ).

\section{Discussion}

Literature reviews indicate that medicinal plant that is the constituent of somina possesses cardiac activity. Previous study on intact frog heart concluded that Somina $(20 \mathrm{mg} / \mathrm{ml})$ is an active herbal medicine that affects cholinergic muscarinic receptors and decreases the heart rate. Another study revealed that somina also decreases the blood pressure (rats) by stimulating the muscarinic receptor. Present study confirmed that somina possess muscarinic receptor activity even when tested by using Langendorff heart assembly for rabbits. The partial agonist competing with the full agonist for receptor occupancy and producing a net decrease in the receptor activation observed with the full agonist alone. ${ }^{7}$ Further the present study revealed that somina is a partial agonists ( $28 \%$ reduction in heart rate), somina bind to and activate receptor (muscarinic receptor), but have only partial efficacy at the receptor relative to a full agonist (Ach $10^{-3} ; 52 \%$ reduction). Further present study is in agreement with previous research that in the presence of a full agonist (Ach $10^{-3}$ ), a partial agonist Somina $(20 \mathrm{mg} / \mathrm{ml})$ act as antagonist. In the present results the administration of combined therapy (Somina + Ach $10^{-3}$ ), Somina competing with the full agonist (Ach $10^{-3}$ ) for the same receptor and thereby reducing the ability of the full agonist to produce its maximum effect (Ach 10 $0^{-3}$ $52 \%$; Somina + Ach $10^{-3} 37 \%$ reduction shown in Figure 1.

Clinically this research is very important,

1. Partial agonists (somina) can be used to activate receptors (muscarinic) to give a desired sub-maximal response when small concentrations of the endogenous ligands (Ach) are present

2. They (Somina) can reduce the overstimulation of receptors when excess amounts of the endogenous ligand (Ach) are present. ${ }^{8}$
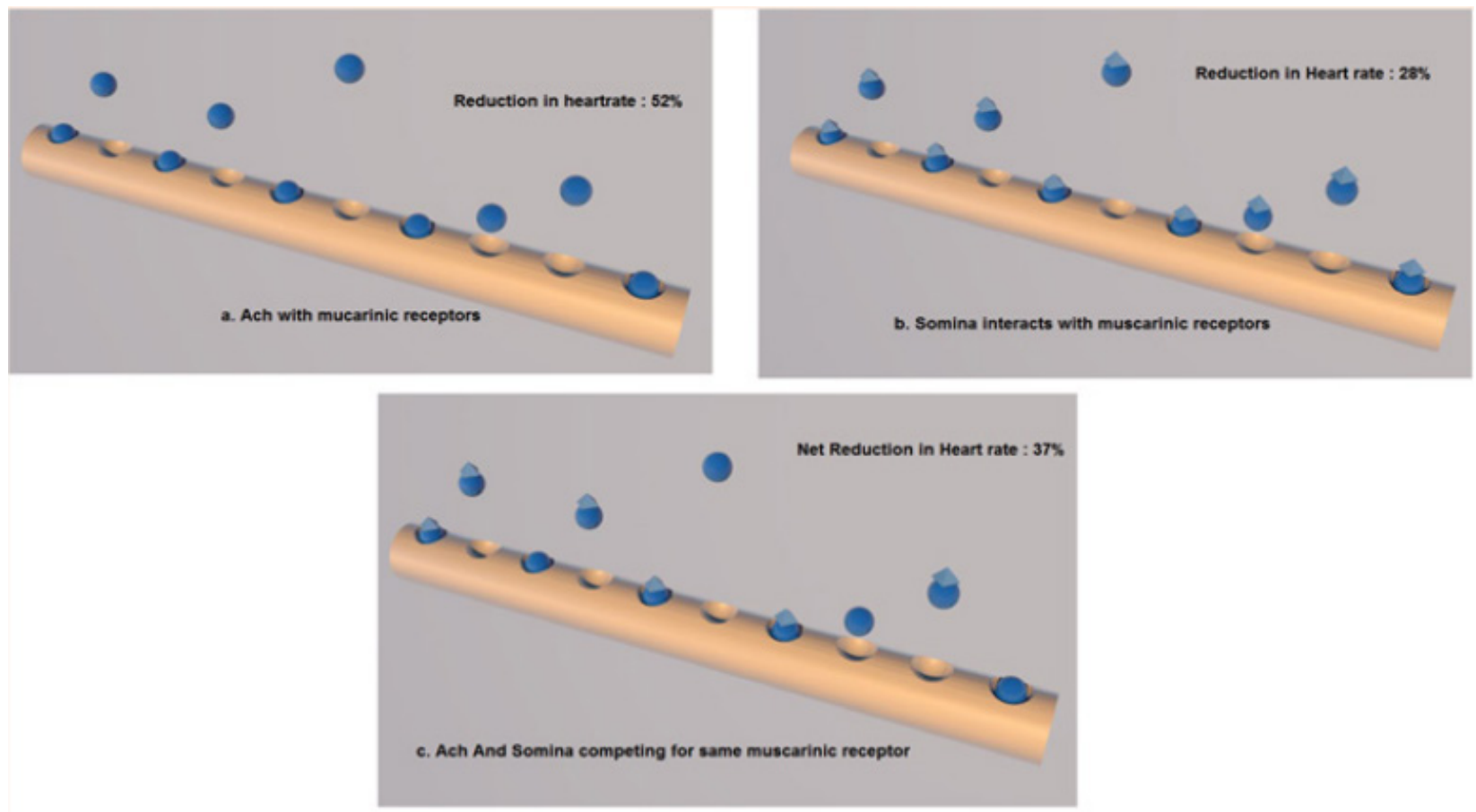

Figure I Proposed graphical illustration indicating the action of full (Ach) and partial (Somina) Agonist with muscarinic receptors. 
Table I Effect of Somina $(20 \mathrm{mg} / \mathrm{ml})$ and various treatments on Heart rate (beats/min).

\begin{tabular}{|c|c|c|}
\hline S. No & Solution & $\begin{array}{l}\text { Reduction in heart rate } \\
\text { mean_S.E. (n) }\end{array}$ \\
\hline I & Somina $(20 \mathrm{mg} / \mathrm{ml})$ & $28.03 \pm 0.08(30)$ \\
\hline 2 & $\operatorname{Ach}\left(10^{-3}\right)$ & $52.4 \mathrm{I} \pm \mathrm{I} .67(30)$ \\
\hline 3 & $\begin{array}{l}\text { Atr } 10^{-3}+\text { Somina } \\
(20 \mathrm{mg} / \mathrm{ml})\end{array}$ & $03.43 \pm 1.02(30)$ \\
\hline 4 & Atr $10^{-3}+\operatorname{Ach}\left(10^{-3}\right)$ & I I.06+2.35 (30) \\
\hline 5 & $\begin{array}{l}\text { Somina } 20 \mathrm{mg} / \mathrm{ml}+ \\
\text { Ach }\left(10^{-3}\right)\end{array}$ & $36.95 \pm 0.14(30)$ \\
\hline
\end{tabular}

The values has been presented as percent of control

\section{Conclusion}

It is concluded that Somina (Herbal preparation) worked as partial agonist.

\section{Acknowledgements}

Authors are grateful to Prof. Dr SI Ahmed (Late), Former Dean Faculty of Pharmacy and Director DrHMIIPHS, Hamdard University Karachi for his support and encouragement at every stage of this study and also to Mr AQ Farooqi, Director, Quality Control Division, Hamdard Laboratories (Waqf), Karachi, Pakistan for the supply of drug samples and Hamdard Foundation for financial support. Authors are thankful to Mr Obaid Altaf, Graphic Designer and Animator, Celeritus Digital Solution for his time and help.

\section{Conflict of interest}

The author declares no conflict of interest.

\section{References}

1. Kandangath RA, Ajay P, Farhath K, et al. Nutritional, Medicinal and Industrial, Uses of Sesame (Sesamum indicum L.) Seeds - An Overview. Agriculturae Conspectus Scientificus. 2010;75(4):159-168

2. Fraser GE. Nut consumption, lipids, and risk of a coronary event. Clin Cardiol. 1999;22(7 Suppl): III11- III15.

3. Andrea H, Michaela H, Jana $\check{\mathbf{S}}$, et al. Poppy seed (Papaver Somniferum $L)$ : Effect of genotype and year of cultivation on variability in its lipid composition. J Microbiol Biotech Food Sci. 2012;1:908-922.

4. Janbaz KH, Latif MF, Saqib F, et al. Pharmacological effects of lactuca serriola 1 in experimental model of gastrointestinal, respiratory, and vascular ailments. Evid Based Complement Alternat Med. 2013;2013:304394.

5. Upaganlawar A, Balaraman R. Cardioprotective Effects of Lagenaria siceraria Fruit Juice on Isoproterenolinduced Myocardial Infarction in Wistar Rats: A Biochemical and Histoarchitecture Study. J Young Pharm. 2011;3(4):297-303.

6. Atanasov AG, Wang JN, Gu SP, et al. Honokiol: A non-adipogenic PPAR agonist from nature. Biochim Biophys Acta. 2013;1830(10):4813-4819.

7. Calvey N, Williams N. Partial agonists. Principles and Practice of Pharmacology for Anaesthetists; 2009. 62 p.

8. Zhu, BT. Mechanistic explanation for the unique pharmacologic properties of receptor partial agonists. Biomed Pharmacother. 2005;59(3):7689. 